\title{
EVALUASI KAPASITAS POMPA PADA SISTEM PENIRISAN TAMBANG BATUBARA
}

\author{
THE EVALUATION OF PUMP CAPACITY ON MINE DRAINAGE SYSTEM
}

\author{
Tomi Arnando ${ }^{1)}$ \\ 1Program Studi Teknik Pertambangan Batubara Politeknik Akamigas Palembang, 30257, Indonesia
}

\begin{abstract}
At mine site of PT Baturona Adimulya, mining activity was conducted using conventional system with the combination of backhoe and truck so that a large basin would be formed along with the progress of the mine. In rainly season, water would swamp the mining front so that it would trigger cessation of coal mining activities. To cope with incoming water, a pump with sufficient amount and capacity was needed to pump the water . the width of rain catchment area in pit 2 of PT Baturona Adimulya was $17.35 \mathrm{Ha}$. Based on the calculation of the total discharge of water entering PT Baturona Adimulya's sump pit 2 at $5,678.88531 \mathrm{~m}^{3} /$ day while the capacity of the three ebara $150 \mathrm{x} 125$ FS4LA pump units used in PT Baturona's 2 sump pit with total pumping discharge of $367.2 \mathrm{~m}^{3} /$ day had not been able to control the water entering the mine. The incompatibility between the amount of incoming and pumped water was the reason foe addition of one pump unit and optimization of the operation pump. To anticipate the occurrence of puddle which a discharge of $312.0180 \mathrm{~m}^{3} /$ hour.
\end{abstract}

Keywords: Rainfall, sump, capacity, pump.

\begin{abstract}
Abstrak: Pada lokasi tambang PT Baturona Adimulya, kegiatan penambangan dilakukan menggunakan sistem konvesional dengan kombinasi antara alat gali muat (backhoe) dan alat angkut (truck) sehingga seiring dengan kemajuan tambang akan terbentuk cekungan yang besar. Pada musim penghujan air akan menggenangi front penambangan sehingga akan menyebabkan terhentinya kegiatan penambangan batubara. Untuk menanggulangi air yang masuk maka diperlukan pompa dengan jumlah dan kapasitas yang memadai untuk memompakan air. Luas daerah tangkapan hujan pada pit 2 PT Batuona Adimulya sebesar 17,35 Ha. Berdasarkan perhitungan total debit air yang masuk ke sump pit 2 PT Baturona Adimulya sebesar 5.678,88531 $\mathrm{m}^{3}$ /hari sedangkan kapasitas tiga unit pompa ebara $150 \times 125$ FS4LA yang digunakan pada sump pit 2 PT Baturona adimulya yaitu dengan total debit pemompaan sebesar 367,2 m3/hari belum mampu mengendalikan air yang masuk ke tambang. Ketidaksesuaian antara besarnya debit air yang masuk besarnya dengan debit air yang dipompakan merupakan dasar diperlukannya penambahan satu unit pompa dan pengoptimalan pengoperasian pompa yang telah beroperasi. Untuk mengantisipasi terjadinya genangan air yang dapat mengganggu aktifitas penambangan batubara, maka direkomendasikan untuk melakukan penambahan satu unit pompa dengan debit 312,0180 $\mathrm{m}^{3} / \mathrm{jam}$.
\end{abstract}

Kata Kunci : Curah Hujan, Sump, Kapasitas, Pompa.

\section{PENDAHULUAN}

\subsection{Latar Belakang}

Penirisan tambang akan identik dengan pengontrolan air tanah dan air permukaan bumi yang biasanya mengganggu aktifitas tambang, baik tambang terbuka, bawah tanah maupun batubara. Curah hujan yang tinggi menyebabkan meningkatnya volume air yang terakumulasi pada dasar tambang sehingga kegiatan penambangan menjadi terganggu dan produksi tidak optimal karena areal kerja menjadi tergenang air. Air yang menggenangi lokasi penambangan merupakan masalah yang utama bagi perusahaan pertambangan karena air yang masuk ke lokasi penambangan dapat mengganggu aktifitas penambangan dan mengakibatkan terhambatnya produksi. Ketika pengontrolan air permukaan maupun air tanah menjadi bagian yang tidak terpisahkan dengan aktifitas penggalian batubara. Maka faktorfaktor yang perlu dipertimbangkan antara lain sistem pengontrolan curah hujan rata-rata, debit air minimum maksimum kualitas air.

Penelitian evaluasi kapasitas pompa pada sistem penirisan tambang telah dilaksanakan oleh Yohanes Gultom, 2013 dkk. dengan judul "Evaluasi Kapasitas Pompa pada Sistem Penirisan Tambang Banko Barat Pit 1 Timur PT Bukit Asam, Tbk. Akan tetapi dalam penelitian kali ini lokasi maupun spesifikasi pompa yang digunakan berbeda dengan penelitian sebelumnya. Oleh karena 
itu, pada penelitian ini akan dilaksanakan di PT Baturona Adimulya.

\subsection{Batasan Masalah}

Batasan masalah yang dibahas dalam penelitian ini diantaranya :

1. Penelitian dilaksanakan di sump pit 2 PT Baturona Adimulya.

2. Permasalahan pompa untuk mengeluarkan air dari sump ke saluran tambang menggunakan pompa ebara 150 x 125 FS4LA

\subsection{Tujuan Penelitian}

Tujuan dari penelitian ini adalah :

1. Menghitung total debit air yang masuk ke sump pit 2 PT Baturona Adimulya

2. Mengetahui sistem pemompaan yang diterapkan.

3. Menganalisis kapasitas pompa yang dibutuhkan dalam mengatasi air yang berada pada sump.

\subsection{Manfaat Penelitian}

Manfaat dari penelitian ini adalah

1. Dapat mengetahui volume air yang masuk ke dalam tambang.

2. Memperkirakan pompa yang sesuai dengan hasil perhitungan data curah hujan rencana yang akan terjadi.

3. Dapat menanggulangi air yang masuk ke sump.

\section{TEORI DASAR}

\subsection{Daur Hidrologi}

Siklus hidrologi atau daur hidrologi adalah gerakan air laut ke udara, kemudian jatuh ke permukaan tanah dan akhirnya kembali mengalir ke laut. Air laut menguap karena adanya radiasi matahari menjadi awan, kemudian awan yang terjadi bergerak ke atas daratan karena tertiup angin. Adanya tabrakan antara butir-butir uap air akibat desakan angin menyebabkan presipitasi. Presipitasi yang terjadi berupa hujan, salju, hujan es dan embun. Setelah jatuh ke permukaan tanah, presipitasi akan menimbulkan limpasan permukaan (surface runoff) yang mengalir kembali ke laut. Dalam perjalanan menuju ke laut beberapa bagian masuk ke dalam tanah (infiltrasi) dan bergerak terus ke bawah (perkolasi) ke dalam daerah jenuh (saturated zone) yang terdapat di bawah permukaan air tanah. Air di dalam daerah ini bergerak perlahan-lahan melewati akuifer masuk ke sungai kemudian ke laut. Air yang masuk ke dalam tanah memberi hidup kepada tumbuhan dan ada di antaranya naik lewat aquifer diserap akar, batang dan daun sehingga terjadi transpirasi.

Daur hidrologi atau daur air merupakan sirkulasi air yang tidak pernah berhenti dari atmosfer ke bumi dan kembali ke atmosfir melalui kondensasi, presipitasi, evaporasi dan transpirasi. Pemanasan air laut oleh sinar matahari merupakan kunci proses daur hidrologi tersebut dapat berjalan secara kontinu. Air berevaporasi kemudian jatuh sebagai presipitasi dalam bentuk hujan, salju, hujan es, hujan gerimis, atau kabut. Pada perjalanan menuju bumi, beberapa presipitasi dapat berevaporasi kembali ke atas, atau langsung jatuh yang kemudian diintersepsi oleh tanaman sebelum mencapai tanah.

Transpirasi adalah penguapan pada tumbuhan melalui bagian bawah daun yaitu stomata. Pemukaan tanah, sungai dan danau juga mengalami penguapan yang disebut evaporasi. Jika kedua proses penguapan di atas terjadi bersamaan maka disebut evapotranspirasi. Akhirnya air yang tidak menguap ataupun mengalami infiltrasi tiba kembali ke laut lewat sungai. Air tanah (groundwater) yang bergerak jauh lebih lambat keluar lewat alur-alur masuk ke sungai atau langsung merembes ke pantai. Maka seluruh siklus telah dijalani, kemudian akan berulang kembali.

\subsubsection{Pemodelan Hidrologi}

Pemodelan hidrologi merupakan representasi matematik dari aliran air dan unsur-unsur pokok lainnya, baik air yang di atas ataupun di bawah permukaan tanah (Maidment, 1991). Penggunaan teknik pemodelan dalam penelitian hidrologi saat ini terlihat sudah sangat berkembang. Penelitian Hidrologi dapat diartikan sebagai pendekatan dalam mempelajari hal-ihwal air dan sumber daya air berdasarkan konsep daur hidrologi dalam suatu sistem DAS dengan komponenkomponen penyusun berupa sistem lahan, 
sumber daya air dan tanah, tanaman dan sistem sosial kemasyarakatan. Perkembangan teknik pemodelan hidrologi DAS tersebut didukung oleh kemajuan teknologi instrumentasi, informasi dan komunikasi, seperti instrumentasi pengukuran, komputasi digital, manajemen data geografis, pengindraan jauh, komunikasi audio dan visual.

Dengan melakukan kajian terhadap pemodelan hidrologi DAS, diharapkan dapat menyusun model hidrologi yang rasional, efektif, efisien yang mampu mengevaluasi dengan cepat serta mampu menduga dampak hidrologi dari perubahan-perubahan yang terjadi, baik alami maupun buatan manusia.

\subsection{Catchment Area}

Penentuan catchment area diperlukan untuk mengetahui besarnya debit air yang masuk ke tambang. Catchment area untuk PT Baturona Adimulya dibatasi hutan yang mengelilingi lokasi penambangan. Air dari catchment area tersebut akan langsung mengalir ke lokasi tambang dalam bentuk limpasan permukaan dan sebagian lagi akan terinfiltrasi dan masuk ke tambang dalam bentuk rembesan air tanah.

\subsection{Curah Hujan}

Curah hujan adalah banyaknya hujan yang terjadi pada suatu daerah. Curah hujan merupakan faktor yang sangat penting dalam perencanaan pertambangan, karena besar kecilnya curah hujan pada suatu daerah tambang akan mempengaruhi besar kecilnya air tambang yang harus ditanggulangi.

Angka- angka curah hujan yang diperoleh merupakan data yang tidak dapat digunakan secara langsung untuk perencanaan pembuatan sarana pengendalian air tambang, tetapi harus diolah terlebih dahulu diolah terlebih dahulu untuk mendapatkan nilai curah hujan yang lebih akurat, curah hujan merupakan data utama dalam perencanaan kegiatan penirisan tambang terbuka.

\subsubsection{Periode Ulang Hujan}

Soemarto, (1995) menyatakan "Periode ulang hujan adalah hujan maksimum yang diharapkan terjadi pada setiap $\mathrm{n}$ tahun. Jika satu data curah hujan mencapai harga tertentu (x) yang diperkirakan terjadi satu kali dalam $n$ tahun, maka $\mathrm{n}$ tahun dapat dianggap sebagai periode ulang dari x". Perhitungan periode ulang dapat dilakukan dengan beberapa metode, tetapi metode yang lazim dipakai adalah metode extreem Gumbel atau lebih lazim disebut metode Gumbel. Penetapan periode ulang hujan sebenarnya lebih ditekankan pada masalah kebijakan dan resiko yang perlu diambil sesuai dengan perencanaan, penetapan periode ulang hujan dapat dilihat pada tabel 2.1

Tabel 2.1 Penetapan Periode Ulang Hujan

\begin{tabular}{|l|c|}
\hline Keterangan & Periode Ulang Hujan \\
\hline Daerah terbuka & $0,5-2$ \\
\hline $\begin{array}{l}\text { Lereng Lereng } \\
\text { Tambang dan } \\
\text { Penimbunan }\end{array}$ & $5-10$ \\
\hline $\begin{array}{l}\text { Pemindahan } \\
\text { Aliran Sungai }\end{array}$ & 100 \\
\hline $\begin{array}{l}\text { Penyaliran } \\
\text { Keliling } \\
\text { Tambang }\end{array}$ \\
\hline Sarana Tambang & 25 \\
\hline $\begin{array}{l}\text { Sumuran } \\
\text { Tambang }\end{array}$ \\
\hline
\end{tabular}

\subsubsection{Daerah tangkapan Hujan}

Daerah tangkapan hujan (catchment area) adalah luasnya permukaan yang apabila terjadinya hujan, maka air hujan tersebut akan mengalir ke daerah yang lebih rendah menuju titik pengaliran. Air yang jatuh kepermukaan sebagian akan meresap ke dalam tanah (infiltrasi), sebagian ditahan oleh tumbuhan (intersepsi), dan sebagian lagi akan mengisi liku-liku permukaan bumi dan akan mengalir ke tempat yang lebih rendah.

\subsubsection{Intensitas Hujan}

Intensitas hujan adalah besarnya curah hujan $(\mathrm{mm})$ yang terjadi dalam waktu tertentu (jam).

\subsection{Debit Air yang Masuk ke Lokasi Tambang}

Debit air yang masuk ke lokasi tambang dipengaruhi oleh debit limpasan, debit air tanah dan evapotranspirasi. Sehingga dapat diketahui jumlah air yang masuk ke dalam tambang. 


\subsubsection{Perhitungan Debit Air Limpasan Permukaan}

Debit air limpasan diperoleh dari air hujan yang sampai dipermukaan tidak mengalami infiltrasi karena kondisi tanah yang gundul dan miring. Perhitungan debit air limpasan yang masuk kedalam pit ditentukan oleh intensitas hujan, luas catchment area, dan koefisien limpasan untuk berbagai jenis tanah.

\subsubsection{Airtanah}

Airtanah adalah air yang bergerak di dalam tanah yang terdapat didalam ruang antar butir-butir tanah yang meresap ke dalam tanah dan bergabung membentuk lapisan tanah yang disebut akuifer (Sosrodarsono, 1993). Lapisan yang mudah dilalui oleh air tanah disebut lapisan permeable, seperti lapisan yang terdapat pada pasir atau kerikil.

\subsubsection{Evaporasi}

Evaporasi adalah proses perubahan molekul di dalam keadaan cair (contohnya air) dengan spontan menjadi gas (contohnya uap air). Proses ini adalah kebalikan dari kondensasi. Umumnya penguapan dapat dilihat dari lenyapnya cairan secara berangsurangsur ketika terpapar pada gas dengan volume signifikan.

Beberapa faktor yang mempengaruhi evaporasi yaitu kondisi klimatologi, yang meliputi : radiasi matahari, temperatur udara, kelembaban udara, dan kecepatan angin.

a. Radiasi matahari

Radiasi matahari merupakan sumber utama panas dan mempengaruhi jumlah evaporasi di atas permukaan bumi, yang tergantung letak pada garis lintang dan musim. Radiasi matahari di suatu lokasi bervariasi sepanjang tahun, yang tergantung pada letak lokasi (garis lintang) dan deklinasi matahari.

\section{b. Temperatur}

Temperatur udara pada permukaan evaporasi sangat berpengaruh terhadap evaporasi. Semakin tinggi temperatur semakin besar kemampuan udara untuk menyerap uap air.

c. Kelembaban udara

Udara lembab merupakan campuran dari udara kering dan uap air. Apabila jumlah uap air yang masuk ke udara semakin banyak, tekanan uapnya juga semakin tinggi. Akibatnya perbedaan tekanan uap semakin kecil, yang menyebabkan berkurangnya laju penguapan. Apabila udara di atas permukaan air sudah jenuh uap air tekanan udara telah mencapai tekanan uap jenuh, di mana pada saat itu penguapan terhenti. Kelembaban udara dinyatakan dengan kelembaban relatif.

d. Kecepatan angin

Kecepatan angin merupakan faktor penting dalam evaporasi. Di daerah terbuka dan banyak angin, penguapan akan lebih besar daripada di daerah yang terlindung dan udara diam.

\subsection{Saluran Tambang}

Pembuatan saluran tambang dilakukan untuk menampung air limpasan permukaan. Saluran ini juga digunakan untuk mengalirkan air hasil pemompaan keluar area penambangan (sungai). Saluran ini harus memenuhi persyaratan-persyaratan sebagai berikut (Suwardi, 2004).

a. Mempunyai dimensi yang sesuai dengan debit aliran air.

b. Mempunyai ruang jagaan yang cukup untuk mengantisipasi adanya sedimentasi di dalam saluran dan menampung terjadinya debit aliran yang diluar rencana.

c. Mempunyai kemiringan saluran yang aman (biasanya 1\%) sehingga kecepatan aliran tidak menimbulkan gerusan pada saluran.

\subsection{Kolam Penampungan (sump)}

Kolam penampungan merupakan tempat yang dibuat untuk menampung air sebelum air tersebut dipompakan. Kolam penampung ini juga dapat berfungsi sebagai tempat mengendapkan lumpur. Tata letak kolam penampung dipengaruhi oleh sistem drainase tambang yang digunakan serta disesuaikan dengan letak geografis daerah tambang dan kesetabilan lereng tambang. Berdasarkan tata letak kolam penampung (sump), sistem penirisan tambang dapat dibedakan menjadi : (Suwardi, 2004)

\subsubsection{Sistem Penirisan Terpusat}

Pada sistem ini sump-sump akan ditempatkan pada setiap jenjang atau bench. Sistem pengaliran dilakukan dari jenjang paling atas menuju jenjang-jenjang yang ada dibawahnya, sehingga akhirnya air akan 
terpusat pada main sump untuk kemudian dipompakan keluar tambang.

\subsubsection{Sistem Penirisan Tidak Terpusat}

Sistem ini diterapkan untuk daerah tambang yang relatif dangkal dengan keadaan geografis daerah luar tambang yang memungkinkan untuk mengalirkan air secara langsung dari sump keluar tambang.

Berdasarkan penempatannya, menurut Suwardi, 2004 sump dapat dibedakan menjadi beberapa jenis, yaitu:

\section{Travelling sump}

Sump ini dibuat pada daerah front tambang. Tujuan dibuatnya sump ini adalah untuk menanggulangi air permukaan. Jangka waktu penggunaan sump ini relatif singkat dan selalu ditempatkan sesuai dengan kemajuan tambang.

\section{Sump jenjang}

Sump ini dibuat secara terencana baik dalam pemilihan lokasi maupun volumenya. Penempatan sump ini adalah pada jenjang tambang dan biasanya di bagian lereng tepi tambang. Sump ini dibuat sebagai sump permanen karena dibuat untuk jangka waktu yang cukup lama dan biasanya dibuat dari bahan kedap air dengan tujuan untuk mencegah meresapnya air yang dapat menyebabkan longsornya jenjang.

\section{Main sump}

Sump ini dibuat sebagai tempat penampungan air terakhir. Pada umumnya sump ini dibuat pada elevasi terendah dari dasar tambang.

\subsection{Aliran Fluida}

Dalam ilmu fisika dinyatakan bahwa energi tidak dapat diciptakan atau dimusnahkan tetapi dapat diubah dari suatu bentuk ke bentuk lainnya. Oleh karena itu, teorema Bernoulli menyatakan bahwa energi total setiap partikel dari fluida sama pada sisi masuk dan sisi keluar sistem pada suatu titik.

\subsection{Pompa dan Pipa}

\subsubsection{Pompa}

Sebuah pompa merupakan alat angkut yang berfungsi memindahkan zat cair dari suatu tempat ke tempat lain. Dalam aktifitas pertambangan pompa berfungsi untuk mengeluarkan air dari tambang. Jenis pompa yang banyak digunakan dalam kegiatan penirisan tambang adalah pompa sentrifugal. Pompa sentrifugal bekerja berdasarkan putaran impeller di dalam pompa. Air yang masuk akan diputar oleh impeller dan selanjutnya dilemparkan ke arah lubang keluar pompa. Pompa jenis ini banyak dipakai ditambang karena mampu mengalirkan lumpur, kapasitasnya besar, dan perawatannya mudah.

Pemasangan pompa dapat dilakuakan dengan cara seri dan paralel. Pemasangan pompa secara seri dilakukan karena head pompa yang digunakan tidak mencukupi untuk menaikkan air sampai ketinggian tertentu. Pemasangan pompa secara paralel dilakukan karena debit pompa yang digunakan tidak mencukupi untuk mengeluarkan air sehingga harus digunakan dua pompa atau lebih yang dipasang secara parallel (Tahara, 2004).

Dalam suatu pemompaan kadangkadang dibutuhkan debit atau tinggi pemompaan (head) yang lebih besar, sedangkan setiap pompa memiliki kemampuan untuk mencapai debit atau head teretentu. Oleh karena itu, dapat diatur dua atau lebih pompa untuk dipasang secara bersamaan, baik secara paralel ataupun secara seri.

a. Hubungan paralel

Pada hubungan paralel pompa dapat terdiri dari beberapa pompa yang sejenis maupun tidak sejenis. Tujuan pemasangan pompa secara pararel adalah untuk memperoleh jumlah aliran volume pemompaan (debit) yang lebih besar. Karena pada hubungan pararel terjadi penjumlahan aliran volume (debit) dengan tinggi pemompaan (head) yang sama besar, yaitu dengan diameter pipa hisab dan diameter pipa buang.

\section{b. Hubungan seri}

Pada hubungan seri, setelah zat cair melalui sebuah pompa, zat cair tersebut akan dibawa ke pompa berikutnya. Pemasangan pompa dapat dilakukan dengan menggunakan beberapa pompa yang sejenis atau pompa yang berbeda. Dalam pemasangan secara seri terjadi penjumlahan tinggi naik (head) pada aliran 
volume atau debit pemompaan yang sama. (Tahara, 2004)

\subsubsection{Pipa}

Pipa adalah saluran tertutup yang digunakan untuk mengalirkan fluida. Pipa untuk keperluan pemompaan biasanya terbuat dari baja, dan berbagai jenis bahan pipa, tetapi untuk tambang saat ini umumnya menggunakan pipa HDPE (High Density Polyethylene). Pada dasarnya bahan apapun yang digunakan harus memperhatikan kemampuan pipa untuk menekan cairan didalamnya karena jika penggunaan pipa tidak sesuai dengan kekuatan pompa atau tekanan pompa yang besar. Sistem perpipaan akan sangat erat dengan daya dan head pompa yang dibutuhkan. Hal ini terjadi karena sistem perpipaan tidak akan terlepas dari adanya gaya gesekan pada pipa, belokan, pencabangan, bentuk katup, serta perlengkapan pipa lainya. Hal ini akan menyebabkan terjadinya kehilangan energi sehingga turunnya tekanan di dalam pipa (Tahara, 2004).

\section{METODOLOGI PENELITIAN}

\subsection{Metode Penelitian}

Metode yang akan dilakukan dalam pengambilan data yang dibutuhkan untuk keperluan penyelesaian penulisan laporan tugas akhir ini adalah.

\section{Studi Literatur}

Studi literatur dilakukan dengan mencari informasi serta teori yang berhubungan dengan desain pit berdasarkan referensi dari buku, jurnal dan laporan tugas akhir sebelumnya.

2. Obsevasi Lapangan

Obsevasi lapangan dilakukan dengan mengamati keadaan lokasi yang akan dilaksanakan tempat penelitian.

\section{Pengumpulan Data}

Dalam penelitian tugas akhir ini terdapat dua jenis data, yaitu :

a. Data primer, yaitu data yang dikumpulkan dengan melakukan pengamatan secara langsung di lapangan seperti panjang pipa, diameter pipa, jenis pompa, jumlah pompa, debit pompa yang ada di lapangan dan lain-lain.

b. Data sekunder, yaitu data yang dikumpulkan berdasarkan referensi dari perusahaan seperti data curah hujan harian dan waktu hujan, peta catchment area, data spesifikasi pompa dan data sistem pemompaan (debit, elevasi hisap dan elevasi buang).

\section{Pengolahan data}

Setelah data didapatkan maka selanjutnya adalah pengolahan data kemudian dilakukan analisis untuk di evaluasi dengan membandingkan debit air yang masuk ke sump dengan debit pemompaan saat ini secara teoritis maupun secara aktual. Tahapan pengolahan dan analisis data sebagai berikut :

a. Perhitungan curah hujan rencana

b. Perhitungan curah hujan maksimum ratarata

c. Perhitungan reduced variate factor

d. Perhitungan reduce variate

e. Perhitungan reduce mean

f. Perhitungan reduce standard variate

g. Perhitungan besarnya simpangan baku

h. Perhitungan intensitas curah hujan

i. Perhitungan debit limpasan permukaan

j. Debit evapotranspirasi

k. Perhitungan $\%$ evapotranspirasi

1. Perhitungan luas daerah yang mengalami evapotranspirasi

m. Debit air yang masuk ke sump

n. Perhitungan debit pompa

o. Head pompa

p. Perhitungan kerugian head akibat gesekan pada pipa

q.Perhitungan kerugian head karena kecepatan

r. Perhitungan head karena belokan

5. Analisa hasil dan pembahasan penelitian ini antara lain :

a. Analisis data total debit air yang masuk ke sump PT Baturona Adimulya.

b. Dapat mengetahui sistem pemompaan yang diterapkan.

c. Dapat mengetahui kapasitas pompa dan mengetahui waktu yang dibutuhkan dalam mengatasi air yang berada di sump. 


\section{HASIL DAN PEMBAHASAN}

\subsection{Hasil}

Dari hasil data primer dan data skunder maka dilakukuan pengolahan data sebagai berikut, yaitu perhitungan curah hujan rencana dan intensitas curah hujan, perhitungan debit limpasan permukaan dan total debit yang masuk ke dalam tambang, perhitungan debit pompa dan head pompa.

\subsubsection{Perhitungan Curah Hujan Rencana dan Intensitas Curah Hujan}

Data curah hujan diperlukan untuk menentukan curah hujan rencana yang akan digunakan dalam analisa penentuan debit air yang masuk ke sump. Perhitungan curah hujan rata-rata menggunakan metode gumbell dengan data curah hujan 5 tahun terakhir yang dimulai dari 2014 sampai 2018 dengan jumlah 30 data. Data yang digunakan adalah data curah hujan yang paling tinggi tiap harinya dari Januari 2014 sampai Desember 2018, dengan curah hujan rata-rata (Xi) 60,2333 $\mathrm{mm} /$ hari, reduce mean (Yn) 0,53622, standart deviation ( $\mathrm{Sn}$ ) $1,13139 \mathrm{~mm} / \mathrm{hari}$, simpangan baku (S) $24,28094 \mathrm{~mm} / \mathrm{hari}$, reduce variate (Yt) 1,4999 (tabel 2.1), dan nilai (k) 0,85176 $\mathrm{mm} /$ hari, setelah semua data di dapat barulah dapat mencari besar curah hujan rencana, nilai curah hujan rencana selama 5 tahun sebesar (Xt) $80,91486 \mathrm{~mm} / \mathrm{hari}$.

Perhitungan intensitas curah hujan (I), untuk mencari intensitas curah hujan digunakan persamaan manonobe dengan nilai curah hujan maksimum (R24), dan lama hujan dengan menggunakan data yang telah diasumsikan oleh PT Baturona Adimulya adalah satu jam, setelah semua data didapat, maka intensitas curah hujan sebesar 60,2333 $\mathrm{m}^{3} /$ hari

\subsubsection{Perhitungan Debit Limpasan, Debit Evapotranspirasi dan Debit Air yang Masuk ke Tambang \\ Untuk menghitung debit air limpasan} terlebih dahulu harus mengetahui luas daerah tangkapan hujan (catchment area). Luas catchment area yang telah ditentukan setelah dilakukan pengukuran oleh mine plan PT Baturona Adimulya untuk sump pit 2 PT
Baturona Adimulya sebesar $17,35 \mathrm{Ha}$ atau $173.522,91 \mathrm{~m}^{2}$.

Air yang masuk ke tambang akan mengalami proses evapotranspirasi. Besarnya evapotranspirasi yang terjadi dapat dihitung dengan intensitas evapotranspirasi (E) sebesar 1,72 x 10-4 $\mathrm{m}^{3} / \mathrm{jam}$ dan luas evapotranspirasi sebesar $1.787,7285973 \mathrm{~m}^{2}$, maka nilai debit evapotranspirasi sebesar 7,377916497 $\mathrm{m}^{3} /$ hari.

Setelah mengetahui luas catchment area untuk menentukan debit air limpasan dengan luas catchment area $(\mathrm{K})$ sebesar $173522,91 \mathrm{~m}^{2}$, intensitas curah hujan (I) $1,6693449 \times 10^{-2}$ m/jam dan koefisien limpasan (C) 0,9 dapat dilihat pada tabel 2.4, maka debit air yang di dapat sebesar $5.678,88531 \mathrm{~m}^{3} /$ hari.

\subsubsection{Perhitungan Debit Pompa Aktual dan Head Pompa}

Dalam penentuan debit pompa rencana terlebih dahulu harus mengetahui total head pompa aktual yang berada dii lapangan. Untuk melakukan perhitungan total head pompa hal yang harus diketahui yaitu debit pompa aktual yang harus diketahui yaitu debit pompa aktual yang dipakai oleh pompa tersebut.

Debit pompa aktual didapat dari pengukuran dilapangan, debit aktual pompa ebara 150 x125 FS4LA adalah sebesar 7,2 $\mathrm{m}^{3} /$ jam dengan jumlah jam kerja pompa 17 jam/hari. Maka total volume pemompaan yang dilakukan oleh ketiga pompa adalah sebesar $367,1388 \mathrm{~m}^{3} /$ hari. Head pada ketiga pompa dapat dihitung berdasarkan data-data dan pengamatan di lapangan pit 2 PT Baturona Adimulya. Untuk nilai head pompa ebara 150 x 125 FS4LA sebesar 20,0067715 m, hal tersebut berhubungan dengan head maksimum yang dimiiki pompa sesuai spesifikasi pompa.

\subsection{Pembahasan}

Dari hasil pengolahan data maka selanjutnya dilakukan analisis total debit air yang masuk ke sump pit 2 PT Baturona Adimulya, analisis sistem pemompaan yang diterapkan pada sump pit 2 PT Baturona Adimulya, serta evaluasi kapasitas pompa dan waktu yang diperlukan untuk memindahkan air yang berada pada sump pit 2 PT Baturona Adimulya. 
4.2.1 Total Debit Air yang Masuk ke Sump Pit 2 PT Baturona Adimulya

Berdasarkan dengan data perhitungan debit air yang masuk ke sump pit 2 PT Baturona Adimulya sebesar 5.671,507394 $\mathrm{m}^{3} /$ hari dengan kapasitas sump sebesar 33.410,37 $\mathrm{m}^{3}$ dengan kapasitas air yang masuk per harinya maka sump pit 2 PT Baturona adimulya masih bisa ditampung

\subsubsection{Sistem Pemompaan}

Dengan sistem pemompaan yang saat ini di terapkan di PT Baturona Adimulya sump pit 2 yaitu sistem pararel dengan letak pompa saat ini berada di elevasi $60 \mathrm{mdpl}$ untuk pipa inlet dan elevasi $80 \mathrm{mdpl}$ untuk pipa outlet dengan perbedaan elevasi $20 \mathrm{~m}$, menggunakan 3 unit pompa ebara $150 \times 125$ FS4LA, dengan instalasi perpipaan menggunakan pipa HDPE (hight density polyetylene ) dengan panjang pipa $100 \mathrm{~m}$.

\subsubsection{Kapasitas Pompa yang Diperlukan untuk Memindahkan Air Dari Sump ke Saluran Tambang}

Dengan melihat kondisi aktual debit ke tiga unit pompa terpasang sebesar $367,2 \mathrm{~m}^{3} /$ hari, tidak bisa mengatasi air yang masuk ke dalam sump. Sehingga dibutuhkan penambahan pompa dengan waktu kerja pompa tetap 17 jam/hari, maka dibutuhkan penambahan satu unit pompa dengan debit $312,0180 \mathrm{~m}^{3} /$ hari atau menambahkan dua unit pompa dengan debit $156,0090 \mathrm{~m}^{3} /$ hari untuk mengatasi air yang masuk ke sump dengan jam kerja pompa tetap $17 \mathrm{jam} / \mathrm{hari}$.

\section{KESIMPULAN DAN SARAN}

\subsection{Kesimpulan}

Dari hasil pembahasan penelitian yang telah dilakukan, maka dapat diperoleh kesimpulan sebagai berikut :

1. Total debit air yang masuk ke sump pit $2 \mathrm{PT}$ Baturona Adimulya adalah sebesar $5.671,5073 \mathrm{~m}^{3} /$ hari, dipengaruhi oleh daerah tangkapan hujan, debit limpasan, intensitas curah hujan, dan curah hujan rencana.

2. Sistem pemompaan yang diterapkan adalah sistem pararel dengan menggunakan tiga unit pompa ebara 150 x 125 FS4LA dan pipa HDPE dengan panjang pipa $100 \mathrm{~m}$

3. Kapasitas tiga unit pompa yang digunakan sekarang sebesar $367,2 \mathrm{~m}^{3} /$ hari dengan jam kerja ke tiga pompa masing-masing 17 jam.

\subsection{Saran}

Berdasarkan dari hasil penelitian yang telah dilakukan, maka ada sedikit saran atau masukan diantaranya :

1. Lakukan perawatan dengan benar agar komponen-komponen pompa yang dilakukan perawatan kinerjanya menjadi lebih maksimal dan umur komponen menjadi lebih lama.

2. Lakukan penambahan satu unit pompa dengan debit $312,0180 \mathrm{~m}^{3} /$ hari atau menambahkan dua unit pompa dengan debit $156,0090 \mathrm{~m}^{3} /$ hari untuk mengatasi air yang masuk ke sump dengan jam kerja pompa tetap $17 \mathrm{jam} / \mathrm{hari}$

3. Lakukan dengan mengganti pompa yang lama dengan dua unit pompa yang baru dengan debit sebesar 156,0090 $\mathrm{m}^{3} /$ hari untuk mengatasi air yang ada di sump dengan jam kerja pompa tetap 17 jam/hari

\section{DAFTAR PUSTAKA}

Bonnier, 1990. Intensitas Curah Hujan. Bandung : Institut Teknologi Bandung.

Endrianto, M. dan Ramli, M. 2013. Perencanaan Sistem Penyaliran Tambang Terbuka Batubara. Tesis, Fakultas Teknik: Universitas Hasanuddin.

Gautama, R. S. 1999. Sistem Penyaliran Tambang. Bandung: Institut Teknologi Bandung.

Gultom, Yohanes. dkk. 2017. Evaluasi Kapasitas Pompa pada Sistem Penirisan Tambang Banko Barat Pit 1 Timur PT Bukit Asam, Tbk. Jurnal Pemompaan Volume 1 No. 2. Tugas Akhir, Fakultas Teknik : Universitas Sriwijaya.

Kite, G.W, 1997. Hydrology for Engineer, 3 rd Edition, McGraw-Hill, New York, 508 p. 
Maidment, 1991. Perancangan Aplikasi Untuk Sistem Penyaliran Pada Tambang Terbuka. Tesis, Fakultas Teknik: Institut Teknologi Bandung.

Olson, R. dan Steven, W. 1993. Dasar-dasar Mekanika Fluida Teknik. Jakarta: PT Gramedia Pustaka.

Seyhan, 1990. Pengantar Hidrogeologi. Yogyakarta: Penerbit Andi.

Soemarto, 1995. Koefisien Limpasan Pada Berbagai Kondisi. Jakarta : PT Gramedia Pustaka.

Soewarno. 1995. Hidrologi Jilid I. Bandung: Nova.

Sosrodarsono. 1993. Hidrologi Untuk Pengairan. Jakarta: PT Pradnya Paramita.

Suwardi, A. 2004. Hidrologi Teknik Edisi 2. Jakarta: Erlangga.

Suwandhi, A. 2004. Perencanaan Sistem Penyaliran Tambang. Diklat Perencanaan Tambang Terbuka. UNISBA.

Tahara, H. 2004. Pompa dan Kompresor. Jakarta: PT Pradnya Paramitha. 
P-ISSN: 2089-5925 E-ISSN: 2621-9328

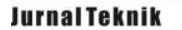

PA TRA

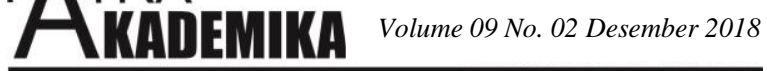

